\title{
Symptomatic manubriosternal joint involvement in rheumatoid arthritis
}

\author{
A DOUBE AND A K CLARKE
}

From the Royal National Hospital for Rheumatic Diseases, Bath

SUMmaRY The manubriosternal joint is commonly involved in rheumatoid arthritis but rarely gives rise to symptoms. A patient is reported with seropositive, erosive rheumatoid arthritis, who developed symptoms resembling pleuritic pain, arising from synovitis of the manubriosternal joint. Treatment with intra-articular steroid injection resolved these symptoms rapidly.

\section{Case report}

A 61 year old female patient with a 14 year history of seropositive, erosive rheumatoid arthritis attended clinic complaining of anterior chest pain. This pain had been present for six months, was localised to the sternal region, and was exacerbated by coughing and by deep inspiration. An unproductive cough had been present over the same period, but she denied any shortness of breath. Although she admitted to only 30 minutes of early morning stiffness, her arthritis was active with many tender, swollen joints, a Health Assessment Questionnaire score of 2.625 , a plasma viscosity of $1.93 \mathrm{cP}$, and a platelet count of $410 \times 10^{9} / 1$. Examination of the cardiovascular and respiratory systems was normal. There was marked soft tissue swelling and tenderness over the manubriosternal joint (Fig. 1). A lateral radiograph of the sternum showed subchondral sclerosis and erosions of the manubriosternal joint (Fig. 2). Aspiration of the manubriosternal joint was unsuccessful, and the joint was injected with triamcinolone hexacetonide $20 \mathrm{mg}$ mixed with $1 \%$ lignocaine, resulting in virtually complete resolution of symptoms over the following week.

\section{Discussion}

Anterior pleuritic pain in patients with rheumatoid arthritis usually arises from pericardial or pleural causes. This patient, however, demonstrates that anterior chest pain of a pleuritic character may also arise from synovitis of the manubriosternal joint. The manubriosternal joint is an amphiarthrodial

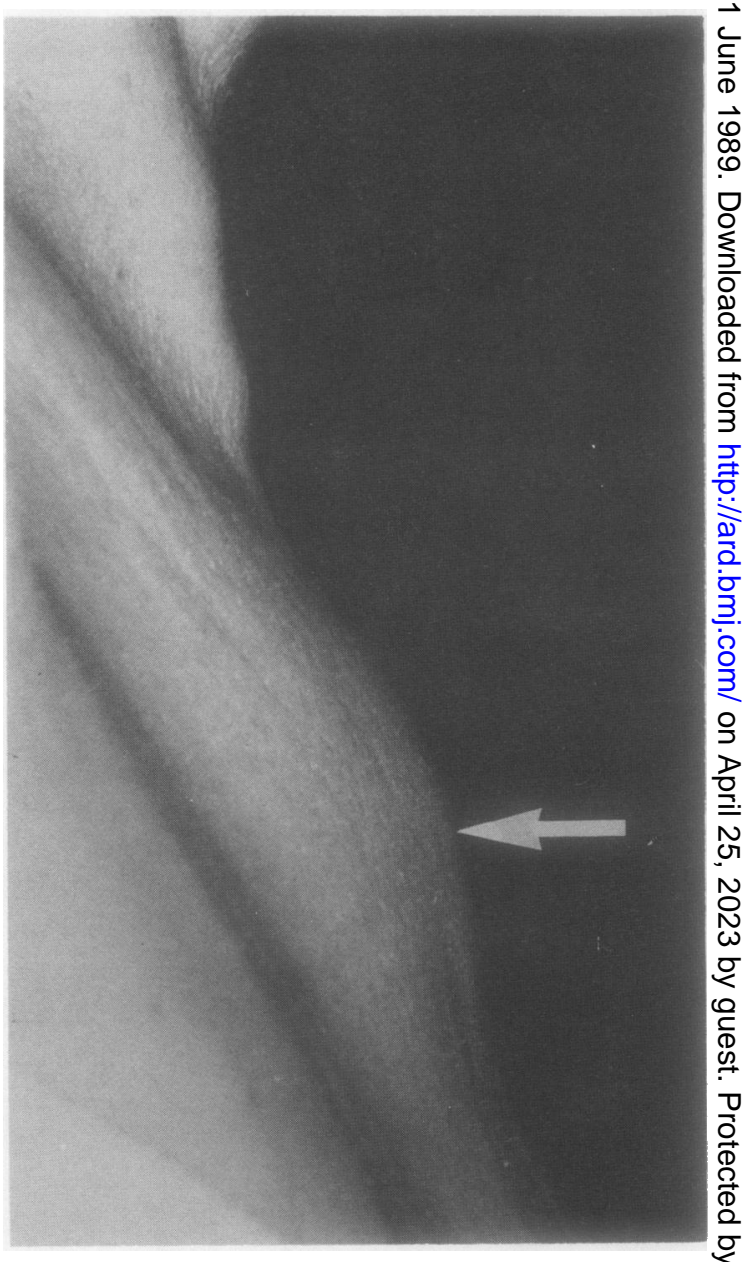

Fig. 1 Soft tissue swelling over the manubriosternal joint. 


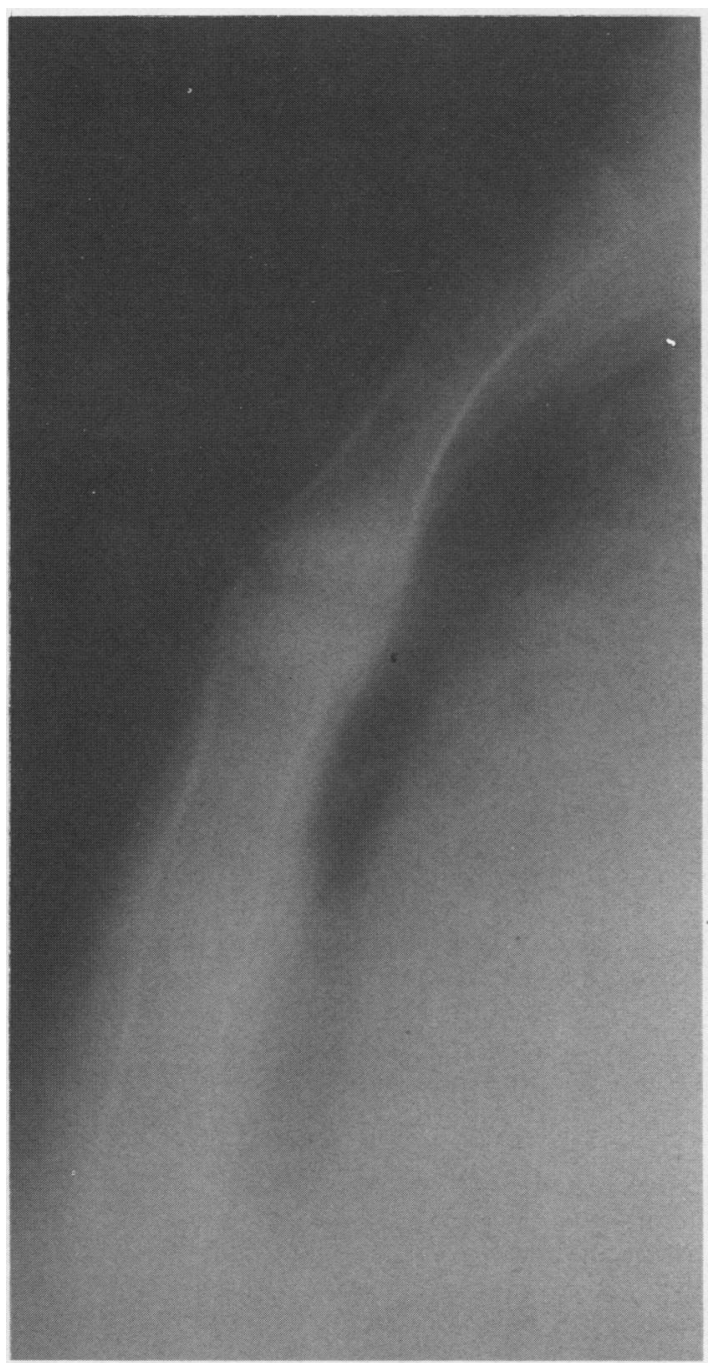

joint containing synovium, ${ }^{\mathrm{i}}$ and radiological change is a frequent finding in patients with rheumatoid arthritis. " Manubriosternal joint subluxation has been documented and is associated with severe cervical spine disease, ${ }^{3}$ as well as with thoracic kyphosis. ${ }^{4}$

Synovitis of the manubriosternal joint is presumably common but because of the relative immobility of the joint is seldom clinically apparent. When symptoms do occur the possibility of superimposed infection needs to be considered. Our patient demonstrates that synovitis of the manubriosternal joint can be symptomatic and that it may respond promptly to intra-articular steroid injection.

\section{References}

1 Kormano M. A microradiological and histological study of the manubrio-sternal joint in rheumatoid arthritis. Acta Rheumatologica Scandinavica 1970; 16: 47-59.

2 Laitinen $H$, Saksanen S, Suoranta H. Involvement of the manubrio-sternal articulation in rheumatoid arthritis. Acta Rheumatologica Scandinavica 1970; 16: 40-6.

3 Khong J K, Rooney P J. Manubrio-sternal joint subluxation in rheumatoid arthritis. $J$ Rheumatol 1982; 9: 712-5.

4 Kelly M C, Hopkinson N D, Zaphiropoulos G C. Manubriosternal joint dislocation in rheumatoid arthritis: the role of the thoracic kyphosis. Ann Rheum Dis 1986; 45: 345-8.

Fig. 2 Lateral radiograph of the manubriosternal joint showing sclerosis and erosion of the joint. 